\title{
Effect of refeeding diets containing cottonseed flour with traces of gossypol on rat liver and testis
}

\author{
BY VÉRONIQUE BERTRAND AND JACQUES BELLEVILLE \\ Université de Bourgogne, Laboratoire de Physiologie de la Nutrition, Faculté des Sciences Mirande, \\ BP 138, 21004 Dijon Cedex, France
}

(Received 30 April 1990-Accepted 10 December 1990)

\begin{abstract}
The aim of the present work was to show that cottonseed flour introduced into rehabilitation diets is not nutritionally harmful. The cottonseed flour obtained from glandless seeds contains traces of gossypol. As gossypol is known to have pathological hepatic and testicular actions, the effects on hepatic variables and on the histological appearance of liver and testis of diets containing cottonseed flour were compared with those without cottonseed flour. Seventy growing male Wistar rats were divided into two groups. The control group (C) received a balanced diet $(200 \mathrm{~g}$ casein $+3 \mathrm{~g}$ methionine $/ \mathrm{kg})$ for $78 \mathrm{~d}$ and the experimental group was fed on a low-protein diet $(20 \mathrm{~g}$ casein $+3 \mathrm{~g}$ methionine $/ \mathrm{kg})$ for $29 \mathrm{~d}$. After the period of protein deprivation, the depleted rats were divided into four groups and each group was refed with a different diet, for $49 \mathrm{~d}$ : a balanced diet ( $200 \mathrm{~g}$ casein $+3 \mathrm{~g}$ methionine $/ \mathrm{kg} ; \mathrm{rC}$ ), maize-soya-bean flour-milk $(60: 30: 5$, by wt; MSM), maize-cottonseed flour-milk $(60: 30: 5$, by wt; MCM) or rice-cottonseed flour-milk $(60: 30: 5$, by wt; $\mathrm{RCM})$. Each diet was supplemented with a vitamin mixture $(10 \mathrm{~g} / \mathrm{kg})$ and a salt mixture $(40 \mathrm{~g} / \mathrm{kg})$. In the liver, protein, total lipid, fatty acid composition and nucleic acid contents were determined after $29 \mathrm{~d}$ of protein deprivation and after $2,14,29,49 \mathrm{~d}$ of refeeding. The refeeding of rats with either diet MSM or RCM promoted a higher growth than that with diet MCM or diet $\mathrm{rC}$. In all groups, a progressive decrease in relative liver weights with age was observed. The highest values were obtained with diets $\mathrm{rC}$ and MSM. After $49 \mathrm{~d}$ of refeeding, the lowest values for lipid, DNA and protein:RNA and the highest values for RNA and RNA:DNA were obtained with the cottonseed diets (MCM and RCM). Rats fed on the cottonseed-flour diets for a $49 \mathrm{~d}$ period after severe protein malnutrition showed no change in size or shape of their hepatocytes compared with those obtained with the control casein diet, and all stages of spermatogenesis occurred normally and spermatozoa were accurately formed. Therefore, our findings show that a low level of gossypol administrated during $49 \mathrm{~d}$, even to an organism weakened by protein malnutrition, does not affect hepatic variables and the histological appearance of liver and testis.
\end{abstract}

Cottonseed flour: Gossypol: Liver: Testes: Rat

Cottonseed flour contains polyphenol gossypol $\left(1,1^{\prime}, 6,6^{\prime}, 7,7^{\prime}\right.$-hexahydroxy-5,5'-diisopropyl-3,3'-dimethyl-2,2' binaphthalene- $8,8^{\prime}$ dicarboxaldehyde). This compound, in the free state, is toxic to non-ruminant animals. Tolerance to gossypol toxicity varies according to the species. Hence, as pigs cannot safely tolerate diets containing more than $0.1 \mathrm{~g}$ free gossypol $/ \mathrm{kg}$, the use of cottonseed flour as a source of protein for this non-ruminant species is largely restricted (Smith \& Clawson, 1965). However, it has been shown that high levels of dietary protein either alleviate or counteract the toxic effects of gossypol in diets for pigs and rats. Hale \& Lyman (1957) reported that pigs fed on a $155 \mathrm{~g}$ protein $/ \mathrm{kg}$ diet containing $0.1 \mathrm{~g}$ free gossypol $/ \mathrm{kg}$ showed no signs of gossypol toxicity. At the $0.15 \mathrm{~g} / \mathrm{kg}$ level, toxicity signs were observed in pigs and death occurred at $0 \cdot 19 \mathrm{~g}$ free gossypol $/ \mathrm{kg}$ and above. Withers \& Carruth (1915) reported that animals fed on cottonseed flour with 
gossypol lost appetite, and post-mortem observations revealed oedema, excessive abdominal fluid, haemorrhagic intestine, and congested livers and kidneys.

In rats, clear toxic effects are recorded only at very high doses (Raghunah \& Giridharan, 1987). In fact, rats are sensitive to lower doses of gossypol than man $(7.5 \mathrm{mg} / \mathrm{kg}$ bodyweight $v .20 \mathrm{mg} / \mathrm{kg}$ ). So, rat is a good model to demonstrate that glandless cottonseed in rehabilitation diets is not nutritionally harmful. Ambrose \& Robbins (1951) showed that in rats, gossypol intake caused a loss of appetite, and that body-weight depression was proportional to the quantity administered. When single doses of $5 \mathrm{mg}{ }^{14} \mathrm{C}$-labelled gossypol were administered to rats the highest radioactivity was found in liver, muscle and kidney, and the highest specific and total activities were observed in the liver (Sharma et al. 1966; Abou-Donia et al. 1970; Smith \& Clawson, 1970).

It has been shown that gossypol can be a specific inhibitor of DNA synthesis in mammalian cells (Wang \& Rao, 1984), but it has no effect on RNA and protein synthesis at a concentration of $10 \mu \mathrm{g} / \mathrm{ml}$ dimethyl sulphoxide (diluting medium) and, hence, has no effect on cell division. In the presence of the drug, cells can enter the $\mathrm{S}$ phase and gossypol does not increase chromosome aberrations. Using Chinese hamster (Cricetulus griseus) ovary cells and human lymphocytes, Ye et al. (1983) showed that gossypol treatment causes no increase in chromosome breakage or polyploidy, but reduces the mitotic index, the synthesis rates of DNA, RNA and protein, and the percentage of viable cells as revealed by the dye exclusion method. In vitro, gossypol is found to be genotoxic by inducing degradation of rat liver DNA (Srivastava \& Padmanaban, 1987). Gross lesions, including hepatomegaly (Holmberg et al. 1988) and acute toxic hepatitis (Rogers et al. 1975), have been observed with gossypol in calves. Lesions reported in young calves include delayed clotting of blood with fatty liver degeneration (Hollon et al. 1958).

Gossypol is cytotoxic to spermatocytes and spermatids, while Sertoli cells, Leydig cells and spermatogonia remained unaffected (National Coordinating Group on Male Infertility, 1978). Gossypol, when given orally to human subjects, induces an infertility effect of $99.9 \%$ (Wichmann, 1982). Gossypol inhibits spermatozoal glycolysis and fructolysis, and immobilizes the sperm cells (Pösö et al. 1980). In human subjects $10 \mathrm{mg}$ gossypol/d induces, after 3 months, a decrease in sperm density and motility (Wichmann et al. 1983; Frick et al. 1988; Stephens et al. 1988). A dose of $20 \mathrm{mg}$ gossypol/d, given for a 3-month period, reduces sperm motility. When this treatment is followed by a weekly dose of $50-$ $60 \mathrm{mg}$, sperm production is blocked (Kalla, 1982). A daily oral dose of $20 \mathrm{mg} / \mathrm{kg}$ for $62 \mathrm{~d}$ to male rats damages epididymal epithelium and sperm (Reyes et al. 1984). A dose of $25 \mathrm{mg}$ gossypol/kg per d inhibits sperm motility by blocking ATP production and utilization and inhibits pyruvate dehydrogenase $(E C$ 1.2.2.2, 1.2.4.1) and ATPase $(E C$ 3.6.1.3, 3.6.1.8) activities (Reyes et al. 1988; Ueno et al. 1988).

The present study was designed to demonstrate that cottonseed-flour diets are not nutritionally harmful. With this intention, investigations were conducted to determine the effects of cottonseed flour on the liver and testis, since these organs are particularly sensitive to gossypol toxicity. As gossypol toxicity varies with the level of protein in the diet, the hepatic and testicular effects of a low gossypol level $(0.012 \mathrm{~g} / 21 \mathrm{~g}$ protein) were studied in rats subjected to severe protein malnutrition, hence on weakened organisms, over a long period of time.

\section{EXPERIMENTAL METHODS}

Seventy male Wistar rats (Iffa-Credo, Lyon, France) weighing 70 (SE 5) g at the beginning of the study, were allowed free access to a balanced diet, containing $200 \mathrm{~g}$ casein $/ \mathrm{kg}$ supplemented with $3 \mathrm{~g}$ methionine $/ \mathrm{kg}$ for $5 \mathrm{~d}$. After this adaptation period to familiarize the rats with a diet in the form of a gruel, they had reached an average body-weight of 100 
(SE 10) $\mathrm{g}$ and they were randomized into two groups. The control group ( $\mathrm{C}$; eighteen rats) was allowed free access to a balanced diet for $78 \mathrm{~d}$, whereas the experimental group (fiftytwo rats) was fed on a low-protein $\operatorname{diet}(\mathrm{M} ; 20 \mathrm{~g}$ casein $+3 \mathrm{~g}$ methionine $/ \mathrm{kg}$ ) for $29 \mathrm{~d}$. The composition of control and experimental diets is shown in Table 1. At the end of this period, the rats subjected to protein malnutrition (PM) were randomized into four equal groups (thirteen rats) fed on different diets for $49 \mathrm{~d}$. This period corresponded to balanced refeeding (BR): balanced diet $(200 \mathrm{~g}$ casein $+3 \mathrm{~g}$ methionine $/ \mathrm{kg} ; \mathrm{rC})$, maize-soya-bean flour-milk diet $(60: 30: 5$, by wt; MSM), maize-cottonseed flour-milk diet $(60: 30: 5)$, by wt; MCM), rice-cottonseed flour-milk diet $(60: 30: 5$, by wt; RCM). Each diet was supplemented with a vitamin mixture $(10 \mathrm{~g} / \mathrm{kg})$ and a salt mixture $(40 \mathrm{~g} / \mathrm{kg})$. The composition of these diets is described in Tables 1 and 2. Maize and rice were tested in association with cottonseed flour because these flours, when associated with soya-bean flour, constitute classical rehabilitation mixtures; by testing the effect of cottonseed flour in comparison with that of soya-bean flour, classical rehabilitation diets could be compared with potential new diets.

Each diet was boiled for $0.5 \mathrm{~h}$ immediately before consumption (diet-water; $1: 2, \mathrm{w} / \mathrm{w}$ ) and was given as a gruel, to simulate the conditions of human consumption. Heating with water caused a decrease (less than $52 \%$ ) in free gossypol level, in a diet containing $360 \mathrm{~g}$ cottonseed flour $/ \mathrm{kg}$ (Bressani et al. 1966). The raw diets with cottonseed flour used in the present study contained about $0.12 \mathrm{~g}$ free gossypol $/ \mathrm{kg}$. After heating, the free gossypol content was reduced by about $50 \%(0.06 \mathrm{~g} / \mathrm{kg})$. Cottonseed flour originating from Bouake (Ivory Coast) was rendered fat-free at $60^{\circ}$ by light petroleum (b.p. $67-70^{\circ}$ ) extraction. The vitamin losses were not determined after heating, but they were assumed to be similar for each diet.

Maize, rice and soya-bean flours and skimmed milk were commercial products. Soya-bean flour had been heated and defatted ( $20 \mathrm{~g}$ lipid $/ \mathrm{kg}$ ).

Rats were kept in wire-bottomed cages at constant temperature $\left(25^{\circ}\right)$ and humidity 60 (SE 5) \% with a 07.00-19.00 hours light cycle. Water and food were supplied ad lib. The food intakes and body-weights were determined daily in each group. After an overnight fast, rats were killed at day 29 of PM, and at days 2, 14, 29, 49 of BR. At each time-point, three rats from each group were anaesthetized using an intraperitoneal injection of sodium pentobarbital $(65 \mathrm{mg} / \mathrm{kg}$ body-weight) and then bled from the abdominal aorta.

The livers were quickly removed, washed with cold saline $(9 \mathrm{~g}$ sodium chloride/l) and weighed. The same hepatic lobe was used to determine protein, nucleic acid and lipid levels.

Protein was assayed according to Lowry et al. (1951). Total hepatic lipids were extracted according to the procedure of Folch et al. (1958) and a known amount of pentadecanoic acid $\left(\mathrm{C}_{15: 0}\right)$ was added before preparation of the butyl esters. The amount of each fatty acid was calculated by comparison with the amount of internal standard $\left(\mathrm{C}_{15: 0}\right)$. The fatty acid compositions were determined using a Becker-Packard Model 419 gas-liquid chromatograph equipped with a $30 \mathrm{~m} \times 0.4 \mathrm{~mm}$ i.d. glass capillary column (coated in the laboratory with Carbowax $20 \mathrm{M}$ ), at a constant temperature of $195^{\circ}$ and a nitrogen flowrate of $3 \mathrm{ml} / \mathrm{min}$. The column was equipped with a ROS injector and the apparatus with a flame-ionization detector. The peak areas were measured using an ENICA 21 integrator. DNA was assayed according to Dische's (1930) method and RNA according to Hatcher \& Goldstein's (1969) technique.

For histological studies only rats fed on BR diets for $49 \mathrm{~d}$ were used. Tissues were sampled, fixed in alcoholic Bouin's solution (Duboscq-Brasil), washed several times in alcoholic solution, and rinsed in ethanol (Gabe, 1968). Tissues were processed for histological examination by routine paraffin-embedding procedures and cutting $5 \mu \mathrm{m}$ sections using an ultramicrotome. Testis and livers were stained by Masson's trichrome 
Table 1. Composition $(\mathrm{g} / \mathrm{kg})$ of control and low-protein diets

\begin{tabular}{lrr}
\hline \hline & Control & Low-protein \\
\hline & & \\
Ingredients & 200 & 20 \\
Milk casein* & 597 & 777 \\
Wheat gluten $\dagger$ & 50 & 50 \\
Saccharose $\$$ & 40 & 40 \\
Maize oilł & 50 & 50 \\
Agar-agar (Fibres)* & 40 & 40 \\
Salt mixture§ & 20 & 20 \\
Vitamin mixture & 3 & 3 \\
Methionine* & 40 & 40 \\
Composition & 189 & 19 \\
Lipid & 50 & 50 \\
Protein (nitrogen $\times 6.25)$ & 658 & 828 \\
Fibre & & \\
Carbohydrate & & \\
\hline
\end{tabular}

* Prolabo, Paris.

$\uparrow$ Etbs Louis François SA, 94100 St Maur, France.

$\ddagger$ Commercial product.

$\S$ UAR B205 (Villemoisson 91360 Epinay-S/Orge). The salt mixture provided the following amounts $(\mathrm{g} / \mathrm{kg}$ diet) : calcium $4 \cdot 0$, potassium $2 \cdot 4$, sodium $1 \cdot 6$, magnesium $0 \cdot 4$, iron $0 \cdot 12$, manganese $0 \cdot 032$, copper $0 \cdot 005$, zinc 0.018 , cobalt 0.0004 , iodine 0.002 .

|| UAR 200 (Villemoisson 91360 Epinay-S/Orge). The vitamin mixture provided the following amounts (mg/kg diet): retinol 12 , cholecalciferol $0 \cdot 125$, thiamin 40 , riboftavin 30 , nicotinic acid 140 , pyridoxine 20 , pyridoxal 300 , cyanocobalamin $0 \cdot 1$, ascorbic acid $1600, \alpha$-tocopherol 340 , menadione 80 , calcium pantothenate 200 , choline 2720 , folic acid 10, $p$-aminobenzoic acid 100 , biotin $0 \cdot 6$.

Table 2. Composition $(\mathrm{g} / \mathrm{kg})$ of experimental diets

\begin{tabular}{|c|c|c|c|}
\hline & $\begin{array}{l}\text { Maize-soya-bean } \\
\text { flour-milk }\end{array}$ & $\begin{array}{l}\text { Maize-cottonseed } \\
\text { flour-milk }\end{array}$ & $\begin{array}{l}\text { Rice-cottonseed } \\
\text { flour-milk }\end{array}$ \\
\hline \multicolumn{4}{|l|}{ Ingredients } \\
\hline Cottonseed flour* & - & 300 & 300 \\
\hline Maize $\ddagger$ & 600 & 600 & - \\
\hline Rice ${ }_{*}^{+}$ & - & - & 600 \\
\hline Soya-bean flour $\dagger$ & 300 & - & - \\
\hline Milk + & 50 & 50 & 50 \\
\hline Salt mixture & 40 & 40 & 40 \\
\hline Vitamin mixture $\|$ & 10 & 10 & 10 \\
\hline \multicolumn{4}{|l|}{ Composition } \\
\hline Lipid & 30 & 48 & 28 \\
\hline$\underset{(\text { nitrogen } \times 6.25)}{\text { Protein }}$ & $201 \cdot 7$ & $210 \cdot 4$ & $217 \cdot 5$ \\
\hline Fibre & 29 & 24 & 35 \\
\hline Carbohydrate & 684 & 668 & 670 \\
\hline
\end{tabular}

* Bouaké Oil mill (Ivory Coast)

† Soyapan; Lecithos.

† Commercial products; skimmed milk.

$\S$ USB, Biological salt mixtures, 21325 salt mixture Bernhart-Tomarelli modified. The salt mixture provides the following amounts $(\mathrm{g} / \mathrm{kg}$ diet): calcium $17 \cdot 20$, potassium $4 \cdot 00$, sodium $4 \cdot 00$, magnesium $2 \cdot 42$, iron $0 \cdot 320$, manganese 0.098 , copper 0.020 , zinc 0.080 , cobalt 0.016 , iodine 0.032 .

\|| Eurobio, Bd St Germain, Paris. The vitamin mixture provides the following amounts (mg/ $\mathrm{kg}$ diet) : retinol 45 , cholecalcif $九$ rol $2 \cdot 5$, thiamin 10 , riboflavin 10 , nicotinic acid 45 , pyridoxine 10 , cyanocobalamin $0 \cdot 0135, \alpha-$ tocopherol 50 , menadione $22 \cdot 5$, calcium pantothenate 30 , choline chloride 750 , folic acid $0 \cdot 9, p$-aminobenzoic acid 50 , biotin $0.2, w$-inositol 50 . 
Table 3. Body-weight and food intake of rats refed on diets containing cottonseed flour with traces of gossypol after a period of protein depletion

(Values are means with their standard errors for three rats/group)

\begin{tabular}{|c|c|c|c|c|c|}
\hline \multirow[b]{2}{*}{ Stage of experiment } & \multirow[b]{2}{*}{ Diet ${ }^{\dagger}$} & \multicolumn{2}{|c|}{$\begin{array}{l}\text { Body-wt } \\
\text { (g) }\end{array}$} & \multicolumn{2}{|c|}{$\begin{array}{c}\text { Food intake } \\
\text { (g/kg body weight) }\end{array}$} \\
\hline & & Mean & $\mathrm{SE}$ & Mean & $\mathrm{SE}$ \\
\hline \multirow{2}{*}{ PM $29 d$} & $\mathrm{C}$ & $252 \cdot 33$ & $4 \cdot 59$ & $77 \cdot 0$ & $2 \cdot 6$ \\
\hline & $M$ & $98 \cdot 75^{* * *}$ & $5 \cdot 82$ & $112 \cdot 7^{* * *}$ & $5 \cdot 6$ \\
\hline \multirow[t]{5}{*}{ BR $2 \mathrm{~d}$} & $\mathrm{C}$ & $288 \cdot 75^{\mathrm{a}}$ & 8.55 & $76 \cdot 1^{\mathrm{a}}$ & 4.9 \\
\hline & $\mathrm{rC}$ & $124 \cdot 75^{b}$ & $5 \cdot 61$ & $106 \cdot 0^{\mathrm{b}}$ & 0.8 \\
\hline & MSM & $137 \cdot 33^{b}$ & 2.72 & $109 \cdot 7^{\mathrm{b}}$ & $3 \cdot 2$ \\
\hline & $\mathrm{MCM}$ & $126 \cdot 25^{b}$ & $3 \cdot 02$ & $86 \cdot 3^{\mathrm{ac}}$ & $9 \cdot 1$ \\
\hline & $\mathrm{RCM}$ & $127 \cdot 00^{b}$ & $6 \cdot 18$ & $97 \cdot 3^{\text {bc }}$ & $7 \cdot 7$ \\
\hline \multirow[t]{5}{*}{ BR $14 \mathrm{~d}$} & $\mathrm{C}$ & $322 \cdot 25^{a}$ & $12 \cdot 73$ & $66 \cdot 0^{\mathrm{a}}$ & 3.6 \\
\hline & $\mathrm{rC}$ & $176.67^{b}$ & $10 \cdot 24$ & $101 \cdot 6^{\mathrm{b}}$ & $9 \cdot 4$ \\
\hline & MSM & $201 \cdot 50^{b}$ & $2 \cdot 27$ & $129 \cdot 1^{\mathrm{b}}$ & $30 \cdot 2$ \\
\hline & $\mathrm{MCM}$ & $170 \cdot 08^{b}$ & $2 \cdot 55$ & $105 \cdot 4^{b}$ & 49 \\
\hline & $\mathrm{RCM}$ & $182 \cdot 17^{b}$ & $9 \cdot 70$ & $117 \cdot 0^{\mathrm{b}}$ & $7 \cdot 3$ \\
\hline \multirow{5}{*}{ BR $29 \mathrm{~d}$} & C & $368 \cdot 83^{\mathrm{a}}$ & 15.90 & $55 \cdot 1^{\mathrm{a}}$ & $4 \cdot 2$ \\
\hline & $\mathrm{rC}$ & $248 \cdot 75^{b}$ & $16 \cdot 61$ & $73 \cdot 3^{\mathrm{b}}$ & $7 \cdot 5$ \\
\hline & MSM & $288 \cdot 50^{\mathrm{b}}$ & 3.98 & $82 \cdot 2^{\mathrm{h}}$ & 1.6 \\
\hline & $\mathrm{MCM}$ & $247.33^{b}$ & 10.63 & $83 \cdot 1^{\mathrm{b}}$ & $5 \cdot 9$ \\
\hline & $\mathrm{RCM}$ & $269 \cdot 50^{\mathrm{b}}$ & $20 \cdot 33$ & $78 \cdot 8^{\mathrm{b}}$ & $14 \cdot 1$ \\
\hline \multirow[t]{5}{*}{ BR $49 \mathrm{~d}$} & C & $421 \cdot 00^{\mathrm{a}}$ & $21 \cdot 77$ & $46 \cdot 4^{a}$ & 0.7 \\
\hline & $\mathrm{rC}$ & $323 \cdot 17^{b}$ & $22 \cdot 16$ & $58 \cdot 0^{\mathrm{b}}$ & $4 \cdot 7$ \\
\hline & MSM & $356.75^{\mathrm{h}}$ & $11 \cdot 70$ & $60 \cdot 2^{b}$ & $3 \cdot 1$ \\
\hline & $\mathrm{MCM}$ & $312 \cdot 50^{\mathrm{b}}$ & 13.50 & $62 \cdot 2^{\mathrm{b}}$ & $4 \cdot 2$ \\
\hline & $\mathrm{RCM}$ & $345 \cdot 00^{b}$ & 33.54 & $59 \cdot 5^{\mathrm{b}}$ & 3.6 \\
\hline
\end{tabular}

a, b. c Means in vertical columns with different superscript letters were significantly different $(P<0.05)$.

Means for group $C$ rats were significantly different from those of group $M$ rats (Student's $t$ test), *** $P<001$.

$\mathrm{C}, \mathrm{rC}$, control diets; $\mathrm{M}$, low protein diet; MSM, maize-soya-bean flour-milk diet; MCM, maize cottonseed flour-milk diet; RCM, rice-cottonseed flour-milk diet; PM, protein malnutrition; BR, balanced refeeding.

$\uparrow$ For details, see Tables 1 and 2.

(Gabe, 1968). The classification of Leblond \& Clermont (1952) was used for identification of the different stages of the spermatogenic cycle which were observed under light microscope with magnifications of 300 -fold and 1150 -fold.

\section{Statistical analysis}

Results are expressed as the arithmetical mean of each group with their standard errors. The significance of the difference between mean values was calculated by Student's $t$ test for paired samples. During BR, statistical evaluation of the data was carried out by variance analysis and by classification of the means using Duncan's new multiple-range test (Duncan, 1955). Differences were considered statistically significant at $P<0.05$.

\section{RESULTS}

\section{Body-weight and food intake}

The rats were stunted from the beginning of PM. After $29 \mathrm{~d}$ of PM, weights of proteindepleted rats were only $39 \%$ of those of control rats (Table 3), whereas food intakes per $\mathrm{kg}$ body-weight were higher in the protein-depleted group $(+46 \%)$. Growth recovery was rapid with the four BR diets. The greatest body-weight gains were observed with MSM and RCM diets and the lowest with $\mathrm{rC}$ and MCM diets. The MCM group consumed more 
Table 4. Relative liver weight, hepatic lipid and protein content of rats refed on diets containing cottonseed flour with traces of gossypol after a period of protein depletion

(Values are means with their standard errors for three rats/group)

\begin{tabular}{|c|c|c|c|c|c|c|c|}
\hline \multirow[b]{2}{*}{ Stage of experiment } & \multirow[b]{2}{*}{ Diet $\uparrow$} & \multicolumn{2}{|c|}{$\begin{array}{c}\text { Liver weight } \\
\text { (g/kg body weight) }\end{array}$} & \multicolumn{2}{|c|}{$\begin{array}{c}\text { Lipid } \\
\text { (mg/g liver) }\end{array}$} & \multicolumn{2}{|c|}{$\begin{array}{c}\text { Protein } \\
\text { (mg/g liver) }\end{array}$} \\
\hline & & Mean & $\mathrm{SE}$ & Mean & $\mathrm{SE}$ & Mean & $\mathrm{SE}$ \\
\hline \multirow[t]{2}{*}{ PM $29 \mathrm{~d}$} & $\mathrm{C}$ & $48 \cdot 5$ & 2.9 & 57.54 & 2.79 & $200 \cdot 00$ & $4 \cdot 04$ \\
\hline & $\mathrm{M}$ & $48 \cdot 1$ & $5 \cdot 1$ & $86 \cdot 37^{* * *}$ & $15 \cdot 54$ & $174.97^{* * *}$ & $20 \cdot 39$ \\
\hline \multirow{5}{*}{$\mathrm{BR} 2 \mathrm{~d}$} & $\mathrm{C}$ & $44 \cdot 8^{\mathrm{a}}$ & $2 \cdot 9$ & $54 \cdot 77^{\mathrm{a}}$ & $9 \cdot 37$ & $189 \cdot 24$ & $7 \cdot 50$ \\
\hline & $\mathrm{rC}$ & $52 \cdot 6^{4}$ & $4 \cdot 9$ & $55 \cdot 37^{\mathrm{a}}$ & $8 \cdot 19$ & 248.63 & 37.55 \\
\hline & MSM & $47 \cdot 9^{\mathrm{a}}$ & $3 \cdot 1$ & $51 \cdot 60^{\mathrm{a}}$ & 4.67 & $220 \cdot 81$ & 24.96 \\
\hline & MCM & $50 \cdot 2^{a}$ & $3 \cdot 4$ & $53.98^{\mathrm{a}}$ & $10 \cdot 89$ & 228.89 & $36 \cdot 64$ \\
\hline & $\mathrm{RCM}$ & $44 \cdot 7^{\mathrm{a}}$ & $3 \cdot 3$ & $39.80^{\mathrm{b}}$ & 1.94 & $214 \cdot 28$ & $22 \cdot 16$ \\
\hline \multirow[t]{5}{*}{ BR $14 \mathrm{~d}$} & $\mathrm{C}$ & $38 \cdot 2^{a}$ & $2 \cdot 0$ & $52 \cdot 47$ & $7 \cdot 19$ & $199 \cdot 13^{\mathrm{a}}$ & $10 \cdot 50$ \\
\hline & $\mathrm{rC}$ & $44 \cdot 7^{\mathrm{b}}$ & 0.6 & 53.43 & $2 \cdot 86$ & $291 \cdot 86^{\circ}$ & 20.63 \\
\hline & MSM & $41 \cdot 0^{\mathrm{abc}}$ & $2 \cdot 3$ & $52 \cdot 07$ & $4 \cdot 16$ & $267 \cdot 71^{\mathrm{ac}}$ & $10 \cdot 31$ \\
\hline & MCM & $43 \cdot 1^{\mathrm{bc}}$ & $2 \cdot 4$ & $49 \cdot 13$ & $2 \cdot 26$ & $284.95^{\circ}$ & $42 \cdot 90$ \\
\hline & $\mathrm{RCM}$ & $38 \cdot 9^{\mathrm{ac}}$ & 1.9 & 48.83 & 1.65 & $212 \cdot 20^{\mathrm{ac}}$ & $55 \cdot 41$ \\
\hline \multirow{5}{*}{ BR $29 \mathrm{~d}$} & $\mathrm{C}$ & $36 \cdot 0^{\mathrm{a}}$ & $2 \cdot 2$ & $53 \cdot 22^{\mathrm{a}}$ & $2 \cdot 74$ & $280 \cdot 67^{a}$ & $10 \cdot 49$ \\
\hline & $\mathrm{rC}$ & $41 \cdot 3^{b}$ & 0.3 & $49 \cdot 73^{\mathrm{ab}}$ & $2 \cdot 76$ & $206 \cdot 39^{\mathrm{b}}$ & 6.88 \\
\hline & MSM & $41 \cdot 3^{n}$ & $1 \cdot 0$ & $49 \cdot 43^{a b}$ & $3 \cdot 74$ & $288 \cdot 35^{\mathrm{a}}$ & 19.00 \\
\hline & MCM & $38 \cdot 8^{\mathrm{ab}}$ & 3.0 & $46.03^{b}$ & 1.25 & $206 \cdot 09^{\mathrm{al} 3}$ & $13 \cdot 79$ \\
\hline & $\mathrm{RCM}$ & $37 \cdot 9^{\mathrm{ab}}$ & $1 \cdot 4$ & $39.53^{c}$ & 3.00 & $180 \cdot 35^{b}$ & 5.82 \\
\hline \multirow[t]{5}{*}{ BR $49 \mathrm{~d}$} & C & $31 \cdot 1^{a}$ & 0.8 & $53 \cdot 00^{\mathrm{a}}$ & $4 \cdot 20$ & $205 \cdot 96^{\mathrm{a}}$ & $18 \cdot 15$ \\
\hline & $\mathrm{rC}$ & $34 \cdot 0^{\mathrm{hc}}$ & 1.5 & $51 \cdot 30^{\mathrm{ab}}$ & 0.99 & $179 \cdot 76^{\mathrm{b}}$ & 8.67 \\
\hline & MSM & $36 \cdot 0^{\mathrm{b}}$ & $0 \cdot 7$ & $45.97^{\mathrm{bu}}$ & 3.60 & $193 \cdot 39^{a b}$ & $2 \cdot 12$ \\
\hline & $\mathrm{MCM}$ & $32 \cdot 1^{\text {ac }}$ & $1 \cdot 2$ & $45 \cdot 37^{\mathrm{bec}}$ & $1 \cdot 39$ & $210 \cdot 15^{a}$ & $6 \cdot 71$ \\
\hline & $\mathrm{RCM}$ & $32 \cdot 4^{a c}$ & $1 \cdot 4$ & $40 \cdot 93^{c}$ & 2.96 & $205 \cdot 17^{a}$ & 9.55 \\
\hline
\end{tabular}

a, b, c Means in vertical columns with different superscript letters were significantly different $P<0.05$.

Means for group $\mathrm{C}$ rats were significantly different from those of group M rats (Student's $t$ test) ${ }^{* * *} P<0.01$.

$\mathrm{C}, \mathrm{rC}$, control diets; M, low protein diet; MSM, maize-soya-bean flour-milk diet; MCM, maize-cottonseed flour-milk diet; RCM, rice-cottonseed flour--milk diet; PM, protein malnutrition; BR, balanced refeeding.

$\dagger$ For details and composition see Tables 1 and 2 and pp. 270-271.

lipids due to the higher dietary content. On the other hand, weight gains were not correlated with food intakes. At the end of the experiment, body-weights with MSM, RCM, rC and MCM diets were still lower $(15 \cdot 2,18 \cdot 1,23 \cdot 3$ and $25 \cdot 9$ respectively), than those of group C. A significant difference between group $\mathrm{C}$ and the experimental groups was recorded, but weights in the four BR groups showed no marked differences.

\section{Liver weight}

At the end of PM, relative liver weight ( $\mathrm{g} / \mathrm{kg}$ body-weight) was the same for control and protein-depleted groups (Table 4). At the beginning of BR, there were no significant differences in relative liver weight between group $C$ and the four experimental groups. After the first period of $B R$, the lowest values were observed in group $C$ rats and this continued throughout the experiment. In each group, relative liver weight decreased with age. At the end of BR, the highest values were observed with diet MSM.

\section{Total lipids}

In the protein-depleted group, PM increased hepatic lipid contents ( $\mathrm{mg} / \mathrm{g}$ liver) by $50 \%$ (Table 4). At the beginning of $\mathrm{BR}$, with the four refeeding diets, total lipids per $\mathrm{g}$ liver decreased rapidly and were, generally, lower than group $\mathrm{C}$ values. The different groups 
presented approximately the same hepatic lipid contents from the beginning to the end of BR excepted for diet RCM which produced the lowest significant values after $29 \mathrm{~d}$ of BR.

\section{Protein}

At the end of PM, liver protein levels (mg/g liver) were similar for group $\mathrm{C}$ and proteindepleted rats (Table 4). Until day 14, the liver protein contents were higher in the four BR groups than in group C. At the end of experiment, the lowest values were observed in group $\mathrm{rC}$.

\section{Fatty acid composition of hepatic total lipids}

The present study was restricted to $29 \mathrm{~d}$ of PM and days 2 and 14 of BR in the five groups (Table 5). PM modified the amounts of some fatty acids: $20: 4 n-6$ and $22: 6 n-3$ decreased to $40 \cdot 6$ and $54 \cdot 8 \%$ of the control values respectively, while $14: 0,16: 0,18: 1 n-7+$ $18: 1 n-9,18: 2 n-6,22: 4 n-6$ and $22: 5 n-6$ increased respectively by $200,163,260,229$, 367 and $279 \%$. After $2 \mathrm{~d}$ of BR, 14:0,16:0,16:1 $n-7,18: 0,18: 1 n-7+18: 1 n-9$, and 24:1n-9 had similar values in all BR groups, whereas $22: 4 n-6$ and $22: 5 n-6$ values were higher than group $\mathrm{C}$ values. After $14 \mathrm{~d}$ of BR, 14:0, 16:1 n-7, 18:1 n-7 and 18:1 $n-9$ levels were lower in diets containing vegetable proteins than in diets $\mathrm{rC}$ and $\mathrm{C}$, and in contrast, the 18:0 level was higher. The 22:5n-6 levels were higher in groups fed on cottonseed flour and 22:6n-3 reached the highest values in MSM group. Similar 20:4 $n-6,22: 4 n-6$ and $24: 0$ values were observed in the five groups.

\section{$D N A$}

This value gives an indication of the number of nuclei and, therefore, of the number of cells per $g$ liver. After $29 \mathrm{~d}$ of PM, liver DNA values of protein-depleted rats did not differ from those of group $\mathrm{C}$ rats (Table 6). After $2 \mathrm{~d}$ of $\mathrm{BR}$, values were significantly lower with diet $\mathrm{RCM}$. After $14 \mathrm{~d}$ of $\mathrm{BR}$, liver DNA of rats fed on both cottonseed-flour diets were significantly lower than those of rats fed on casein or soya-bean-flour diets. At the end of the experiment, values did not differ between the groups.

\section{Protein: DNA}

This value indicates the amount of protein per cell; PM decreased this value by $24 \%$ (Table 6). At day 2 of BR, group $C$ values decreased by $26.5 \%$ in comparison with group $C$ values obtained at the end of PM. This could indicate that hypertrophy or cellular maturation was followed by a hyperplasia phase, as we have previously shown in pancreas (Prost et al. 1988). From day 14, the highest values were obtained with both cottonseed-flour diets due to their lower liver DNA levels. After $29 \mathrm{~d}$ of BR, diet RCM presented significantly lower values than those of diets MCM and MSM and diet MSM values were significantly higher than those of diets $\mathrm{rC}$ and $\mathrm{C}$. At the end of the experiment, values did not differ significantly from one group to another.

\section{$R N A$}

Values were not significantly different between group $C$ and protein-depleted rats after $29 \mathrm{~d}$ of PM (Table 7). At day 2 of BR, diet RCM values were higher than those of diet MCM (Table 7). At day 14 of BR, the highest values were observed in group RCM and the lowest ones in group $\mathrm{rC}$. At the end of the experiment, the findings obtained with both diets containing cottonseed flour showed higher concentrations of RNA (mg/g liver). 


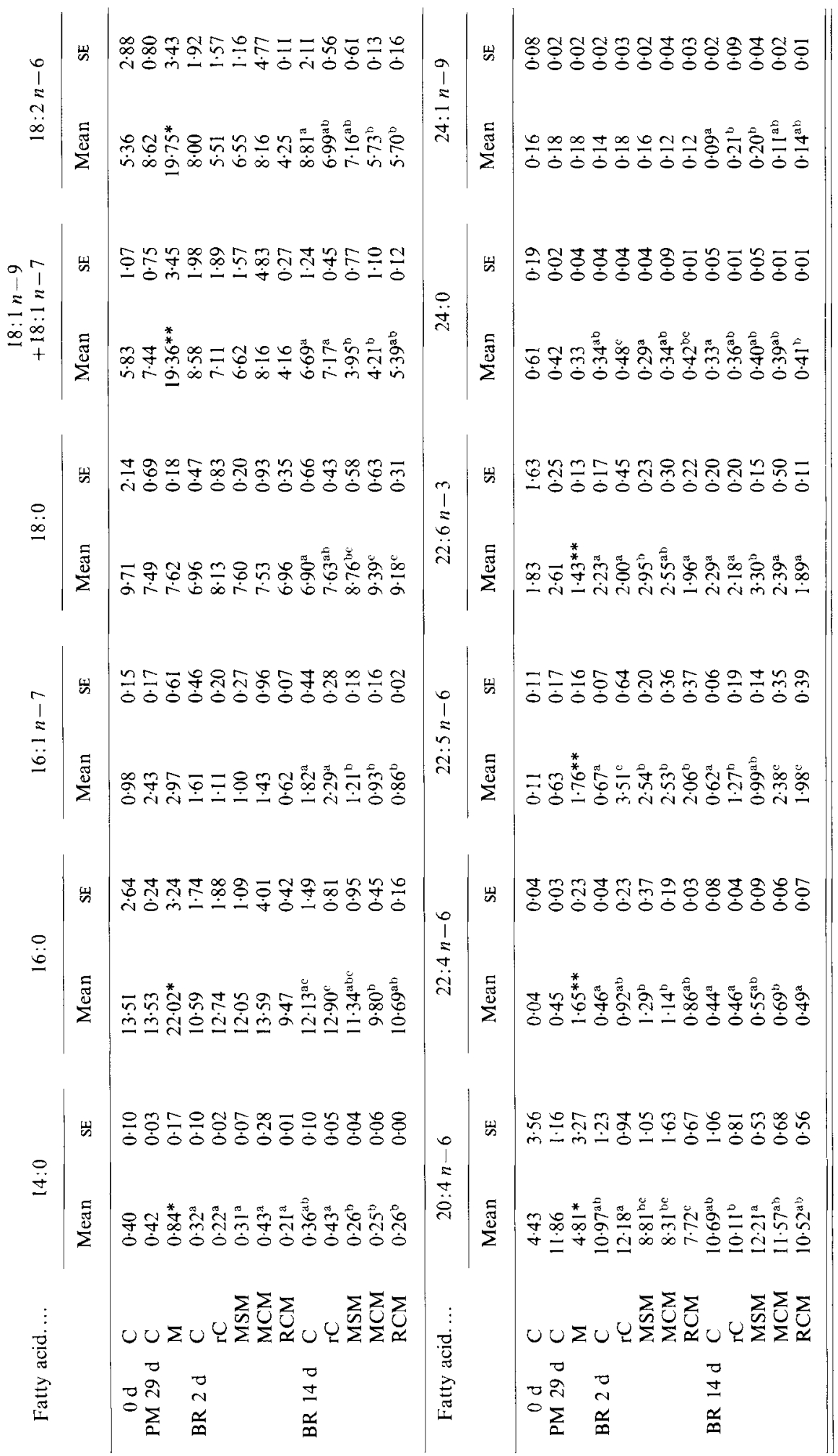


Table 6. Liver DNA content and liver protein:DNA of rats refed on diets containing cottonseed flour with traces of gossypol after a period of protein depletion

(Values are means with their standard errors for three rats/group)

\begin{tabular}{|c|c|c|c|c|c|}
\hline \multirow[b]{2}{*}{ Stage of experiment } & \multirow[b]{2}{*}{$\operatorname{Diet} \uparrow$} & \multicolumn{2}{|c|}{$\begin{array}{l}\text { Liver DNA } \\
\text { (mg/g tissue) }\end{array}$} & \multicolumn{2}{|c|}{$\begin{array}{l}\text { Liver protein:DNA } \\
\qquad(\mathrm{mg} / \mathrm{mg})\end{array}$} \\
\hline & & Mean & $\mathrm{SE}$ & Mean & $\mathrm{SE}$ \\
\hline \multirow[t]{2}{*}{ PM $29 d$} & $\mathrm{C}$ & 2.47 & 0.09 & $80 \cdot 97$ & 3.60 \\
\hline & M & 2.83 & 0.30 & $60 \cdot 87^{* * *}$ & $2 \cdot 39$ \\
\hline \multirow[t]{5}{*}{ BR $2 \mathrm{~d}$} & $\mathrm{C}$ & $3 \cdot 18$ & $0 \cdot 10$ & $59 \cdot 51^{\mathrm{a}}$ & $0 \cdot 72$ \\
\hline & $\mathrm{rC}$ & 3.07 & 0.06 & $80.99^{\mathrm{bc}}$ & $12 \cdot 42$ \\
\hline & MSM & $3 \cdot 25$ & 0.23 & $67.94^{a c}$ & $3 \cdot 03$ \\
\hline & $\mathrm{MCM}$ & $3 \cdot 28$ & 0.09 & $69 \cdot 78^{\mathrm{ac}}$ & $9 \cdot 48$ \\
\hline & $\mathrm{RCM}$ & $2 \cdot 32$ & 0.40 & $92 \cdot 36^{\mathrm{b}}$ & $7 \cdot 54$ \\
\hline \multirow{5}{*}{ BR $14 \mathrm{~d}$} & $\mathrm{C}$ & $3 \cdot 15^{\mathrm{a}}$ & $0 \cdot 27$ & $63 \cdot 22^{\mathrm{a}}$ & $5 \cdot 27$ \\
\hline & $\mathrm{rC}$ & $3.44^{\mathrm{a}}$ & 0.25 & $84 \cdot 84^{a}$ & 6.55 \\
\hline & MSM & $3.64^{\mathrm{a}}$ & 0.09 & $73 \cdot 54^{\mathrm{a}}$ & 1.35 \\
\hline & MCM & $1 \cdot 35^{b}$ & 0.35 & $211.07^{\mathrm{b}}$ & 87.69 \\
\hline & $\mathrm{RCM}$ & $1 \cdot 82^{b}$ & 0.45 & $116.59^{b}$ & $98 \cdot 26$ \\
\hline \multirow{5}{*}{ BR $29 \mathrm{~d}$} & $\mathrm{C}$ & $3 \cdot 34^{a}$ & 0.14 & $84.03^{\mathrm{acc}}$ & 6.48 \\
\hline & $\mathrm{rC}$ & $2.93^{\mathrm{ab}}$ & $0 \cdot 22$ & $70 \cdot 44^{\mathrm{ac}}$ & 5.41 \\
\hline & MSM & $2.68^{\mathrm{bc}}$ & 0.23 & $107 \cdot 59^{\mathrm{b}}$ & 15.63 \\
\hline & MCM & $2 \cdot 25^{\circ}$ & $0 \cdot 27$ & $91 \cdot 59^{\mathrm{bc}}$ & $13 \cdot 20$ \\
\hline & $\mathrm{RCM}$ & $2 \cdot 76^{b}$ & $0 \cdot 23$ & $65 \cdot 34^{a}$ & $5 \cdot 59$ \\
\hline \multirow[t]{5}{*}{ BR $49 \mathrm{~d}$} & C & 2.91 & $0 \cdot 78$ & $70 \cdot 68$ & $17 \cdot 85$ \\
\hline & $\mathrm{rC}$ & $1 \cdot 78$ & $0 \cdot 13$ & $100 \cdot 99$ & 11.93 \\
\hline & MSM & $2 \cdot 48$ & $0 \cdot 65$ & 77.98 & 21.96 \\
\hline & MCM & 2.09 & 0.07 & $100 \cdot 55$ & $6 \cdot 33$ \\
\hline & $\mathrm{RCM}$ & $1 \cdot 79$ & $0 \cdot 33$ & 114.62 & $31 \cdot 71$ \\
\hline
\end{tabular}

a, b, c Means in vertical columns with different superseript letters were significantly different $(P<0.05)$. Means for group $\mathrm{C}$ rats were significantly different from those of group $\mathrm{M}$ rats (Student's $t$ test) $* * * P<0 \cdot 01$.

C, rC, control diets; M, low protein diet; MSM, maize-soya-bean flour-milk diet; MCM, maize-cottonseed flour-milk diet; RCM, rice-cottonseed flour-milk diet; PM, protein malnutrition; BR, balanced refeeding.

$\dagger$ For details and composition see Tables 1 and 2 and pp. 270-271.

\section{Protein: $R N A$}

The highest values indicated the most elevated protein synthesis per RNA unit. Malnutrition decreased this ratio by $23.5 \%$ (Table 7 ). At the beginning of BR, values increased quickly, except in group RCM which showed the lowest values. At the end of experiment, the lowest values were observed with both cottonseed diets and the highest with diet MSM.

\section{$R N A: D N A$}

This ratio indicates the RNA content per cell. After $2 \mathrm{~d}$ of $\mathrm{BR}$, the greatest value was obtained with diet RCM and with both diets containing cottonseed flour after $14 \mathrm{~d}$ of experiment. After $29 \mathrm{~d}$ of BR, the lowest values were achieved with diets $\mathrm{rC}$ and RCM and the highest ones with diet MSM. After $49 \mathrm{~d}$ of BR, the highest values were observed in both groups consuming cottonseed flour.

\section{Liver}

Livers of experimental rats before sampling were as well irrigated as the control rats. Hepatic lobules of animals which consumed diets MCM and RCM had a morphological appearance similar to that of group $C$ rats. The number, size and shape of hepatocytes were similar for all groups (Plate 1). Portal areas, hepatic artery, portal vein and bile duct 
Table 7. Liver RNA content, liver protein: RNA and liver $R N A: D N A$ of rats refed on diets containing cottonseed flour with traces of gossypol after a period of protein depletion

(Values are means with their standard errors for three rats/group)

\begin{tabular}{|c|c|c|c|c|c|c|c|}
\hline \multirow[b]{2}{*}{ Stage of experiment } & \multirow[b]{2}{*}{$\operatorname{Diet}^{\dagger}$} & \multicolumn{2}{|c|}{$\begin{array}{l}\text { Liver RNA } \\
\text { (mg/g tissue) }\end{array}$} & \multicolumn{2}{|c|}{$\begin{array}{l}\text { Liver protein : RNA } \\
(\mathrm{mg} / \mathrm{mg})\end{array}$} & \multicolumn{2}{|c|}{$\begin{array}{c}\text { Liver RNA: DNA } \\
(\mathrm{mg} / \mathrm{mg})\end{array}$} \\
\hline & & Mean & $\mathrm{SE}$ & Mean & $\mathrm{SE}$ & Mean & $S E$ \\
\hline \multirow[t]{2}{*}{ PM 29 d } & $\mathrm{C}$ & $4 \cdot 20$ & $0 \cdot 80$ & $47 \cdot 62$ & $13 \cdot 25$ & $1 \cdot 70$ & 0.09 \\
\hline & $\mathbf{M}$ & $5 \cdot 94$ & 0.88 & $29 \cdot 46$ & $2 \cdot 79$ & $2 \cdot 09$ & $0 \cdot 13$ \\
\hline \multirow[t]{5}{*}{ BR $2 d$} & $\mathrm{C}$ & $2 \cdot 84^{\mathrm{a}}$ & $0 \cdot 43$ & $66 \cdot 63^{3}$ & $9 \cdot 53$ & $0.89^{a}$ & 0.13 \\
\hline & $\mathrm{rC}$ & $4 \cdot 83^{\mathrm{ab}}$ & $1 \cdot 53$ & $51 \cdot 48^{a b}$ & $20 \cdot 50$ & $1 \cdot 58^{\mathrm{a}}$ & 0.53 \\
\hline & MSM & $3 \cdot 52^{\mathrm{a}}$ & $0 \cdot 36$ & $62 \cdot 73^{\mathrm{ab}}$ & $12 \cdot 31$ & $1 \cdot 08^{\mathrm{a}}$ & $0 \cdot 19$ \\
\hline & $\mathrm{MCM}$ & $4 \cdot 20^{a 13}$ & $1 \cdot 13$ & $54 \cdot 50^{\mathrm{ab}}$ & $14 \cdot 58$ & $1 \cdot 28^{a}$ & 0.37 \\
\hline & RCM & $6 \cdot 06^{b}$ & 0.62 & $35 \cdot 36^{b}$ & 3.95 & $2 \cdot 6 \mathrm{I}^{\mathrm{b}}$ & $0 \cdot 30$ \\
\hline \multirow[t]{5}{*}{ BR I4 d } & $\mathrm{C}$ & $2 \cdot 93^{\mathrm{a}}$ & $0 \cdot 10$ & $67 \cdot 96^{a}$ & $4 \cdot 42$ & $0 \cdot 93^{a}$ & $0 \cdot 10$ \\
\hline & $\mathrm{rC}$ & $2 \cdot 11^{b}$ & 0.75 & $138 \cdot 32^{\mathrm{b}}$ & $66 \cdot 38$ & $0 \cdot 6 \mathrm{I}^{\mathrm{a}}$ & 0.27 \\
\hline & MSM & $3 \cdot 00^{\mathrm{a}}$ & $0 \cdot 23$ & $89 \cdot 24$ & $8 \cdot 68$ & $0 \cdot 82^{\mathrm{a}}$ & 006 \\
\hline & $\mathrm{MCM}$ & $3.33^{\mathrm{a}}$ & 0.03 & $85.57^{a b}$ & $13 \cdot 46$ & $2 \cdot 47^{\mathrm{b}}$ & 0.70 \\
\hline & $\mathrm{RCM}$ & $4.25^{c}$ & $0 \cdot 17$ & $49 \cdot 93^{\circ}$ & 15.05 & $2 \cdot 34^{b}$ & 0.76 \\
\hline \multirow[t]{5}{*}{ BR $29 d$} & $\mathrm{C}$ & $5 \cdot 53^{\mathrm{a}}$ & $1 \cdot 17$ & $50 \cdot 75^{\mathrm{ab}}$ & $14 \cdot 30$ & $1.65^{\mathrm{ar}}$ & 0.29 \\
\hline & $\mathrm{rC}$ & $3 \cdot 14^{b}$ & $0 \cdot 42$ & $65 \cdot 73^{a}$ & $9 \cdot 05$ & $1 \cdot 07^{\mathrm{d}}$ & 0.22 \\
\hline & MSM & $6 \cdot 54^{\mathrm{a}}$ & $0 \cdot 15$ & $44 \cdot 09^{\mathrm{b}}$ & $2 \cdot 76$ & $2 \cdot 45^{b}$ & 0.21 \\
\hline & $\mathrm{MCM}$ & $3.86^{b}$ & 0.08 & $53 \cdot 39^{\mathrm{ab}}$ & $4 \cdot 49$ & $1 \cdot 72^{\mathrm{a}}$ & 0.25 \\
\hline & $\mathrm{RCM}$ & $3.22^{b}$ & 0.34 & $56 \cdot 0 I^{\text {ab }}$ & $7 \cdot 14$ & $1 \cdot 17^{\mathrm{ed}}$ & 0.07 \\
\hline \multirow{5}{*}{ BR $49 \mathrm{~d}$} & $\mathrm{C}$ & $3 \cdot 84^{a}$ & 0.06 & $53 \cdot 57^{\mathrm{ab}}$ & $5 \cdot 49$ & $1 \cdot 32^{4}$ & 0.48 \\
\hline & $\mathrm{rC}$ & $3 \cdot 79^{a}$ & $0-58$ & $47 \cdot 43^{t b}$ & $7 \cdot 44$ & $2 \cdot 13^{\mathrm{Ac}}$ & 0.46 \\
\hline & MSM & $3 \cdot 17^{\mathrm{a}}$ & 0.29 & $61 \cdot 01^{a}$ & $5 \cdot 81$ & $1 \cdot 28^{\mathrm{a}}$ & 0.37 \\
\hline & $\mathrm{MCM}$ & $6 \cdot 25^{b}$ & 0.67 & $33 \cdot 62^{\mathrm{c}}$ & $3 \cdot 73$ & $2 \cdot 99^{\mathrm{be}}$ & 0.28 \\
\hline & $\mathrm{RCM}$ & $5.96^{\mathrm{b}}$ & 0.58 & $34 \cdot 42^{\mathrm{c}}$ & 3.75 & $3.33^{\mathrm{b}}$ & 0.66 \\
\hline
\end{tabular}

$a, b, c, d$ Means in vertical columns with different superscript letters were significantly different $(P<0.05)$.

$\mathrm{C}, \mathrm{rC}$, control diets; $\mathrm{M}$, low protein diet; MSM, maize-soya-bean flour-milk diet; MCM, maize-cottonseed flour-milk diet; RCM, rice-cottonseed flour--milk diet; PM, protein malnutrition; BR, balanced refeeding.

$\dagger$ For details and composition see Tables 1 and 2 and pp. 270271.

presented no sign of physiological impairment, and no sign of necrosis was observed. Hepatocyte nuclei and nucleoli from rats fed on cottonseed diets were similar to those of group $\mathrm{C}$ rats. There were no traces of intracellular or extracellular alteration.

\section{Testis}

Groups C and MCM presented tubules at stage VI while group RCM presented tubules at stage $V$ (Plate 2). Testes of experimental animals presented the same size and morphological aspect as those of group $\mathrm{C}$ rats with active seminiferous tubules. After $49 \mathrm{~d}$ of BR with diets MCM and RCM there was no sign of seminiferous tubule degeneration: tubule lumen appeared similar to that of group $C$, germinal cells were against the basal membrane, spermatozoa were seen in the seminiferous lumen, and at high magnification, the seminiferous epithelium cycle was active. At each stage, the spermatogenic cells observed were normal: Sertoli cells, spermatids, spermatogonia (SA and SB) and spermatocytes were present. Spermatozoa were formed without dissociation between head and flagels as described by Radigue et al. (1988). Other microscopy sections were observed (100 for each group), and all stages of the seminiferous epithelium cycle were comparable with those of group $C$ sections. The stages observed, after $49 \mathrm{~d}$, indicated that the spermatogenic cycle presented no abnormalities (different size or number of cells or incomplete steps) and that the morphological pattern was unchanged. 


\section{DISCUSSION}

Our results showed that group $\mathrm{C}$ values varied with age; therefore, it was necessary to compare the values of experimental groups with group $C$ values on the same day of experiment. Moreover, as the animals were different from one time-point to another, interindividual variations could explain some of the changes in each group during the experiment and between the groups at the same time-point. Nevertheless, the comparisons are relevant because the values of the five groups were measured in parallel, under the same conditions.

In previous papers (Bertrand \& Belleville, 1988, 1989) we have shown that nutritional efficiency varied with diet, though the energetic intake per $\mathrm{kg}$ body-weight was similar between the four experimental groups. The highest nitrogen digestibility coefficients were obtained with diets $\mathrm{C}$ and $\mathrm{rC}$, the lowest with diet RCM followed by diet MCM and then diet MSM. Apparent lipid digestibility coefficient values were of the same order. The highest $\mathrm{N}$ balances were obtained with diets $\mathrm{C}$ and $\mathrm{rC}$, followed by diets MSM and RCM and the lowest values with diet MCM. Moreover, diets MSM and RCM involved the highest protein intake, while diets $\mathrm{MCM}$ and $\mathrm{rC}$ promoted a more elevated lipid consumption. These findings might explain why the highest body-weight gain occurred with diets MSM and RCM and the lowest with diets MCM and rC.

Relative liver weights were not modified by PM and increased more in the experimental groups during the BR period than in group $C$. This indicates that liver growth was facilitated by the four rehabilitation diets. However, relative liver weights decreased with age in all groups. At the end of the experiment, rats on diets MSM and $\mathrm{rC}$ had the highest relative liver weights, in comparison with those of rats on the diets containing cottonseed flour. These findings might result from higher levels of isoleucine and leucine in diets $\mathrm{rC}$ and MSM. However, at this time, the highest relative liver weights were associated with the lowest protein concentrations.

The liver lipid content was increased in the protein-depleted group. It has already been shown that liver steatosis induced by PM is due to reduced serum very-low-densitylipoprotein apolipoprotein levels which impair the transport of liver triacylglycerols and lead to an accumulation of liver lipids (Meghelli-Bouchenak et al. 1987). From day 2 of refeeding, the lowest lipid hepatic level in group RCM might be due to a lower lipid intake because diet RCM had the lowest lipid content (Table 2).

After 1 month of a low-protein diet, liver DNA and RNA levels in group C and proteindepleted rats were similar. In the protein-depleted group a normal level of hepatic RNA with a normal hepatic protein level might indicate that the mRNA was accurately translated due to decreased amino acid bioavailability. At the end of the experiment, in rats fed on both diets containing cottonseed flour, the hepatic RNA levels and RNA:DNA values were highest, while the protein: RNA values were the lowest, suggesting that, at this time, transcription of RNA might have been raised. These diets supported an increase in hepatic RNA synthesis or a decrease in RNA catabolism, or both, as confirmed by the rise in RNA per cell. Protein and RNA levels were not impaired but protein:RNA was decreased, indicating that transduction was diminished with these diets. However, transcription was not impaired since the hepatic protein contents were not decreased with either cottonseed-flour diet.

In the liver, according to sample times, our results illustrate three different patterns: when DNA per g liver was increased, for example, in group MCM at day 2 of refeeding, cell number per tissue unit was higher and consequently cell size was decreased. In this case, DNA was high whereas RNA was low. These variations indicate that cell division prevailed over protein synthesis. This characterizes hyperplasia. After $2 \mathrm{~d}$ of refeeding, with other 
diets such as diet RCM the opposite phenomenon was observed, cells were large but less numerous. Their RNA content was elevated, proving that protein synthesis prevailed over cell division. This characterizes hypertrophy. In intermediate cases such as diet MSM, after $2 \mathrm{~d}$ of refeeding, medium protein and nucleic acid levels were observed. The relative importance of cell division and protein synthesis were equilibrated.

In previous reports (Narce et al. 1988; Meghelli-Bouchenak et al. 1989) we have discussed the changes in fatty acid composition of total hepatic lipids in protein-depleted groups, and in the present study the same results have been obtained. In particular the level of $18: 2 n-6$ was increased and that of $20: 4 n-6$ was diminished. A period of $2 \mathrm{~d}$ of $\mathrm{BR}$ was sufficient to restore most of the fatty acid levels in total lipids to group $C$ values, except for $22: 4 n-6$ and $22: 5 n-6$ levels which were raised again, probably because the 18:2 $n-6$ intake was increased by the four rehabilitation diets. Moreover, these results indicate that PM has immediate effects on $\triangle 6$ - and $\triangle 5$-hepatic microsomal desaturases which are involved in the transformation of $18: 2 n-6$ into $20: 4 n-6$. Narce et al. (1988) have proved that protein malnutrition decreases the activities of $\triangle 5$ - and $\triangle 6$-desaturases, but at day 2 of refeeding, changes in metabolic state involve a rebound effect of hepatic desaturase activities which are higher than group $C$ values. The lowest (not significant) concentrations of 18:2n-6,20:4n-6,22:4n-6 and 22:6n-3 in group RCM rat liver at day 2 of refeeding might be explained by the reduced levels of $18: 2 n-6$ and $18: 3 n-3$ in these diets and a lower intake. At day 14 of refeeding, in rats fed on diets containing vegetable proteins, the decreases in $14: 0,16: 0,16: 1 n-7$, and $18: 1 n-9+18: 1 n-7$ levels in hepatic lipids might be due to their hepatic lipid contents and their lipid digestive efficiencies which were lower than those promoted by diet $\mathrm{rC}$. The richest 22:6n-3 level obtained with diet MSM was probably attributable to its higher $18: 3 n-3$ content.

Liver micrographs observed after $49 \mathrm{~d}$ of refeeding, revealed no cytotoxic effects of gossypol at the low dose of $0.6 \mathrm{~g} / \mathrm{kg}$ heated cottonseed flour in diets MCM and RCM. Size and form of hepatocytes were unchanged compared with hepatocytes of rats receiving the casein diet without gossypol. Our histological study confirmed the absence of impairment on hepatic variables caused by glandless cottonseed flour.

At the end of the experiment, rats had become sexually mature. Ghafoorunissa (1980) studied PM effects on testis which indicated that malnutrition inhibits testis weight gain. Seminiferous scores were decreased compared with group $C$, seminiferous tubules were degenerated and spermatocytes were located in the seminiferous lumen. At sexual maturity, the spermatogenesis cycle was blocked at the stage reached previously. Gossypol at 20 $\mathrm{mg} / \mathrm{kg}$ body-weight is highly effective in reducing sperm (Hadley et al. 1981). Rats treated with increasing daily doses of gossypol $(0,1,5,10 \mathrm{mg} / \mathrm{kg})$ for 1 week revealed that gossypol has a direct inhibitory effect on steroidogenesis (Lin et al. 1981). Gafvels et al. (1984) have shown that gossypol at $1 \mathrm{mg} / \mathrm{kg}$ body-weight, for 5 weeks, had no effect on sex organ weights, blood flow to testes and morphology of testes. A $10 \mathrm{mg} / \mathrm{kg}$ dose caused signs of tubular degeneration, reduced testosterone concentration, and involution of the ventral prostate and seminal vesicles.

The findings of Chinese scientists on the anti-fertility effect of sub-toxic doses of gossypol (Sang, 1983; Quian \& Wang, 1984) in man and male animals have changed the concept of gossypol toxicity. Its use as a contraceptive for humans has been confirmed but its toxicity and various side-effects on humans have hampered further human and animal studies. Studies regarding its mechanism as an anti-fertility compound have shown that gossypol decreases or inhibits sperm motility (Hadley et al. 1981; Liu et al. 1981 ; Chongthammakun et al. 1986), degenerates tubular epithelium in rats (Xue, 1981), alters the ultrastructure of mature spermatozoa (Hadley et al. 1981; Hoffer, 1982) and reduces spermatozoal substrate utilization (Tso \& Lee, 1982). 
Raghunah \& Giridharan (1987) stated that gossypol is cytotoxic to spermatocyte and spermatozoon.

In our study, analysis of testis micrographs, showing various developed stages indicated that the spermatogenesis cycle was complete. These stages of seminiferous tubule cycles were not sensitive in the long-term to traces of gossypol. Another study on sperm motility is required before we can conclude that no apparent effect is observed at low doses. Presently, it can be stated that after PM, low intakes of gossypol do not involve any toxic effects, therefore the type of cottonseed flour used in the present investigation can be added to rehabilitation diets.

\section{Conclusion}

BR by diets containing cottonseed flour, shows that $0.06 \mathrm{~g}$ gossypol $/ \mathrm{kg}$ in heated flours, with a high level of cottonseed protein, is too low to develop severe toxicity symptoms in liver weakened by a long period of PM. More especially, cottonseed diets do not impair hepatic division and protein synthesis. Only hepatic RNA levels are higher in rats fed on diets containing cottonseed flour for $49 \mathrm{~d}$, in comparison with those containing casein or soya-bean flour. Moreover, in our experimental conditions, no change in liver and seminiferous tubule morphology was observed after $49 \mathrm{~d}$ of the recovery phase with cottonseed diets containing a low gossypol content.

The authors thank the laboratory of Zoology (Dijon) for their training in microscopy, $\mathrm{Mr}$ F. Graf for his scientific advice, Mr J. Gresti for his technical assistance in chromatography and Mrs A. Magnet, a linguist at the University of Burgundy, for her help with the English language.

\section{REFERENCES}

Abou-Donia, M., Lyman, C. M. \& Dieckert, J. W. (1970). Metabolic fate of Gossypol: The metabolism of ${ }^{14} \mathrm{C}-$ gossypol in rats. Lipids $\mathbf{5}, 938-946$.

Ambrose, A. M. \& Robbins, D. J. (1951). The chronic oral toxicity of cottonseed meal and cottonseed pigment glands. Journal of Nutrition 43, 357-370.

Bertrand, V. \& Belleville, J. (1988). Utilisation nutritionnelle de la farine de coton comparée à celle du soja, pour des rats en croissance ayant subi une malnutrition protéique. (Nutritional utilization of cottonseed flour compared to that of soyd-bean flour in growing rats subjected to protein deprivation). Compte-Rendus de la Société de Biologie 182, 94-104.

Bertrand, V. \& Belleville, J. (1989). Efficacité de la farine de coton sur la récupération nutritionnelle de jeunes rats ayant subi une carence protéique sévère. (Efficiency of cottonseed flour on nutritional recovery of young rats subjected to severe protein depletion). Nutrition Clinique et Métabolisme 3, 17-25.

Bressani, R., Elias, L. G. \& Braham, J. E. (1966). Cottonseed protein in human foods. In World Protein Resources, Advances in Chemistry Series, vol. 57, pp. 75-100. Washington DC: American Chemical Society.

Chongthammakun, S., Ekavipat, C., Sanitwongse, B. \& Pavasuthipaisit, K. (1986). Effects of gossypol on human and monkey sperm motility in vitro. Contraception 34, 323-331.

Dische, Z. (1930). Some new characteristic color tests for thymonucleic acid and microchemica for determining the same in animal organs by means of these tests. Mikrochemistry 8, 4-32.

Duncan, D. B. (1955). Multiple range and multiple F-tests. Biometrics 11, 1-42.

Folch, J., Lees, M. \& Sloane Stanley, G. H. (1958). Simple method for isolation and purification of total lipids from animal tissues. Journal of Biological Chemistry 226, 497-509.

Frick, J., Aulitzky, W. \& Kalla, N. R. (1988). Clinical microdose study of gossypol : Effect on sperm motility and renal function. Contraception 37, 153-162.

Gabe, M. (1968). In Techniques histologiques, pp. 113-223 [M. Gabe, editor]. Paris: Masson et cie.

Gafvels, M., Wang, J., Berch, A., Damber, J. E. \& Selstam, G. (1984). Toxic effects of the antifertility agent gossypol, in selected organs of male rats. Toxicology 32, 325-333.

Ghafoorunissa, B. (1980). Undernutrition and fertility of male rats. Journal of Reproduction and Fertility 59 , $317-320$.

Hadley, M. A., Lin, Y. C.\& Dym, M. (1981). Effects of gossypol on the reproductive system of male rats. Journal of Andrology 2, 190-199.

Hale, F. \& Lyman, C. M. (1957). Effect of protein level in the rations on gossypol tolerance in growing-fattening pigs. Journal of Animal Science 16, 364-367. 
Hatcher, D. W. \& Goldstein, G. (1969). Improved methods for determination of RNA and DNA. Analytical Biochemistry 31, 42-48.

Hoffer, A. P. (1982). Ultrastructural studies of spermatozoa and the epithelial lining of the epididymis and vas deferens in rat treated with gossypol. Archives of Andrology 8, 233-246.

Hollon, B. F., Waugh, R. K., Wise, G. H. \& Smith, F. H. (1958). Cottonseed meals as the primary protein supplement in concentrate feeds for young calves. Journal of Dairy Science 41, 286-294.

Holmberg, C. A., Weaver, L. D., Guterbock, W. M., Genes, J. \& Montgomery, P. (1988). Pathological and toxicological studies of calves fed a high concentration cotton seed meal diet. Veterinary Pathology 25, 147-153.

Kalla, N. R. (1982). Gossypol. The male antifertility agent. IRCS Medicine and Sciences 10, 766-769.

Leblond, C. P. \& Clermont, Y. (1952). Definition of the stages of the cycle of the seminiferous epithelium in the rat. Annals of New York Academy of Sciences 55, 548-573.

Lin, T., Murono, E. P., Osterman, J., Nankin, H. R. \& Coulson, P. B. (1981). Gossypol inhibits testicular steroïdogenesis. Fertility and Sterility 35, 563-566.

Liu, Z. Q., Liu, G. Z., Hei, L. S., Zhang, R. A. \& Yu, C. Z. (1981). Clinical trial of gossypol as a male antifertility agent. In Recent Advances in Fertility Regulation, pp. 160-163 [C. Chang, D. Griffin and A. Woolman, editors]. Geneva: Atar.

Lowry, O. H., Rosebrough, N. H., Farr, A. L. \& Randall, R. J. (1951). Protein measurement with the folin phenol reagent. Journal of Biological Chemistry 193, 265-275.

Meghelli-Bouchenak, M., Boquillon, M. \& Belleville, J. (1987). Time course of changes in rat serum apolipoproteins during the consumption of different low protein diets followed by a balanced diet. Journal of Nutrition 117, 641-649.

Meghelli-Bouchenak, M., Boquillon, M. \& Belleville, J. (1989). Hepatic steatosis and serum very low density lipoproteins during two types of protein malnutrition followed by balanced refeeding. Nutrition 5, 321-329.

Narce, M., Poisson, J. P., Belleville, J. \& Chanussot, B. (1988). Time-course effects of protein malnutrition on hepatic fatty acids $\triangle 6$ and $\triangle 5$ desaturation in the growing rat. British Journal of Nutrition 60, 389-402.

National Coordinating Group on Male Infertility (1978). Gossypol: a new antifertility agent for males. Chinese Medical Journal 4, 417-421.

Pösö, H., Wichmann, K., Janne, J. \& Luukkainen, T. (1980). Gossypol, a powerful inhibitor of human spermatozoal metabolism. Lancet ii, 885-886.

Prost, J., Belleville, J. \& Valantin-Rollet, C. (1988). Effects of age and protein malnutrition followed by balanced refeeding on the synthesis and excretion of four pancreatic hydrolases in growing rats. British Journal of Nutrition 60, 619-631.

Quian, S. Z. \& Wang, A. G. (1984). Gossypol: a potential antifertility agent for males. Annual Review of Pharmacology and Toxicology 24, 329-360.

Radigue, C., Soufir I. C., Couvillers, M. L., Dantec, H. C. \& Folliot, R. (1988). Early effects of gossypol on the testis and epididymis in the rat. Reproduction Nutrition et Développement 28, 1329-1338.

Raghunah, M.\& Giridharan, N. (1987). Effect of the maie antifertility agent gossypol, on pancreatic and intestinal proteases in the rat. Nutrition Reports International 36, 757-761.

Reyes, J., Allen, J., Tamphaichitr, N., Bellve, A. R. \& Benos, D. J. (1984). Molecular mechanisms of gossypol action on lipid membranes. Journal of Biological Chemistry 259, 9607-9615.

Reyes, J., Borriero, L. \& Benos, D. J. (1988). A bioenergetic model of gossypol action: Effects of gossypol on aduit rat spermatogenic cells. American Journal of Physiology 254, C564-C570.

Rogers, P. A. M., Henaghan, T. P. \& Wheelers, B. (1975). Gossypol poisoning in young calves. Irish Veterinary Journal 29, 9-13.

Sang, G. W. (1983). Effects of gossypol on male reproduction. In Hormones in Normal and Abnormal Human Tissues, pp. 215-240 [K. Fotherby and D. Pal, editors]. Berlin and New York: Walter de Gruyter \& Co.

Sharma, M. P., Smith, F. H. \& Clawson, A. J. (1966). Effects of levels of protein and gossypol, and length of feeding period on the accumulation of gossypol in tissues of swine. Journal of Nutrition 88, 434-438.

Smith, F. H. \& Clawson, A. J. (1965). Effect of diet on accumulation of gossypol on the organs of swine. Journal of Nutrition 87, 317-321.

Smith, F. H. \& Clawson, A. J. (1970). The effects of dietary gossypol on animals. Journal of American Oil Chemists' Society 47, 443-447.

Srivastava, A. K. \& Padmanaban, G. (1987). Gossypol mediated DNA degradation. Biochemical and Biophysical Research Communications 946, 1515-1522.

Stephens, D. T., Critchlow, L. M. \& Hoskins, D. D. (1988). Mechanism of inhibition by gossypol of glycolysis and motility of monkey spermatozoa in vitro. Journal of Reproduction and Fertility 69, 447-452.

Tso, W. W. \& Lee, C. S. (1982). Gossypol uncoupling of respiratory chain and oxidative phosphorylation in ejaculated boar spermatozoa. Contraception 25, 649-655.

Ueno, H., Sahni, M. K., Segal, S. J. \& Koide, S. S. (1988). Interaction of gossypol with sperm macromolecules. Contraception 37, 333-341.

Wang, Y.\& Rao, P. N. (1984). Effect of gossypol on DNA synthesis and cell cycle progression of mammalian cells in vitro. Cancer Research 44, 35-38.

Wichmann, K., Kapyaho, K., Sinervirta, R. \& Janne, J. (1983). Effect of gossypol on the motility and metabolism of human spermatozoa. Journal of Reproduction and Fertility 69, 259-264. 

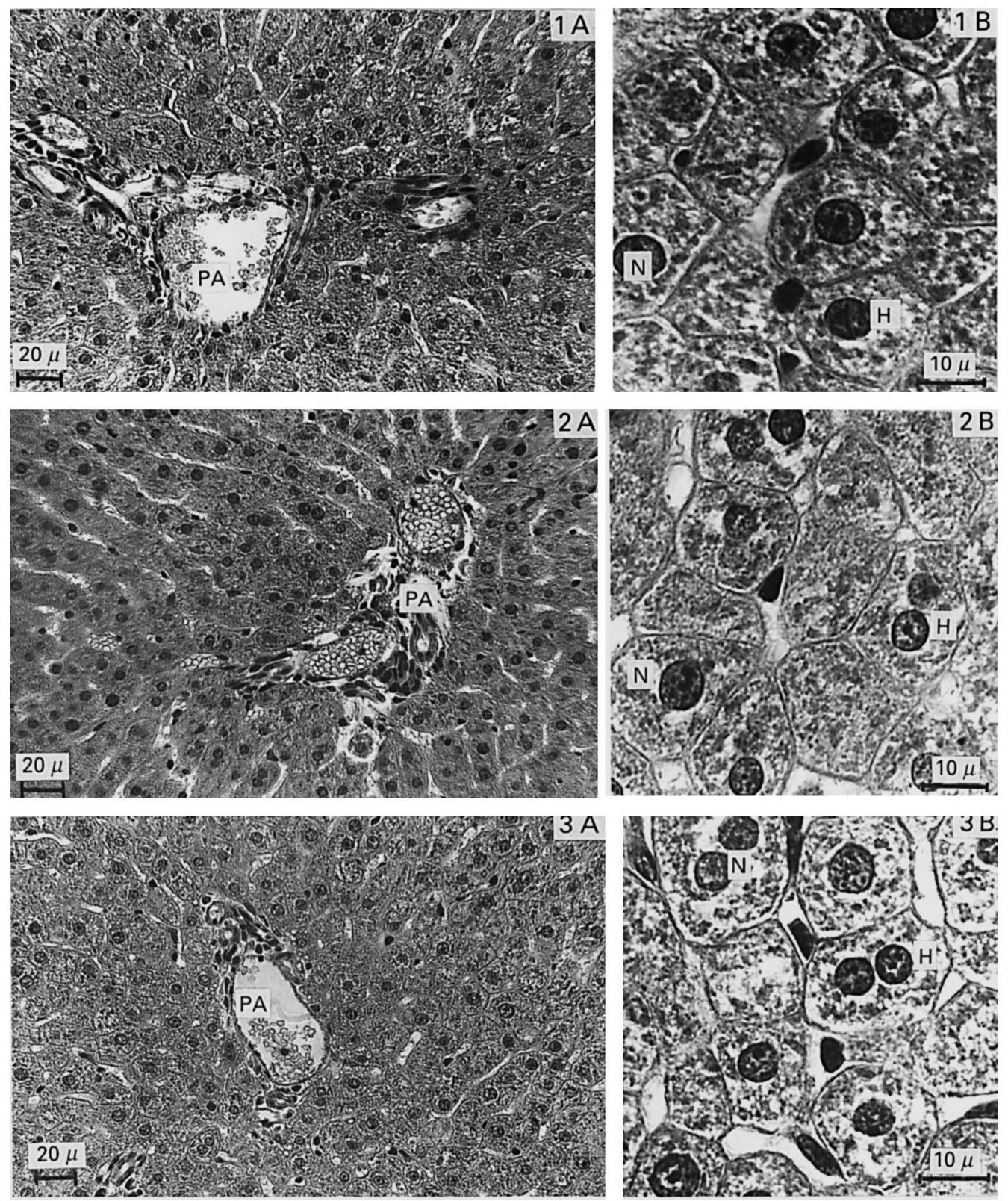

Plate 1. Liver structure of rats fed on control (1 A, 1 B), maize-cottonseed flour-milk (2A, $2 \mathrm{~B})$ and rice cottonseed flour-milk ( $3 \mathrm{~A}, 3 \mathrm{~B}$ ) diets (for details of composition, see Tables 1 and 2 and pp. 270-271) after a period of protein depletion. PA, portal area formed by a hepatic artery, bile duct and a hepatic portal vein; $\mathrm{N}$, nucleus; $\mathrm{H}$, hepatocyte. 

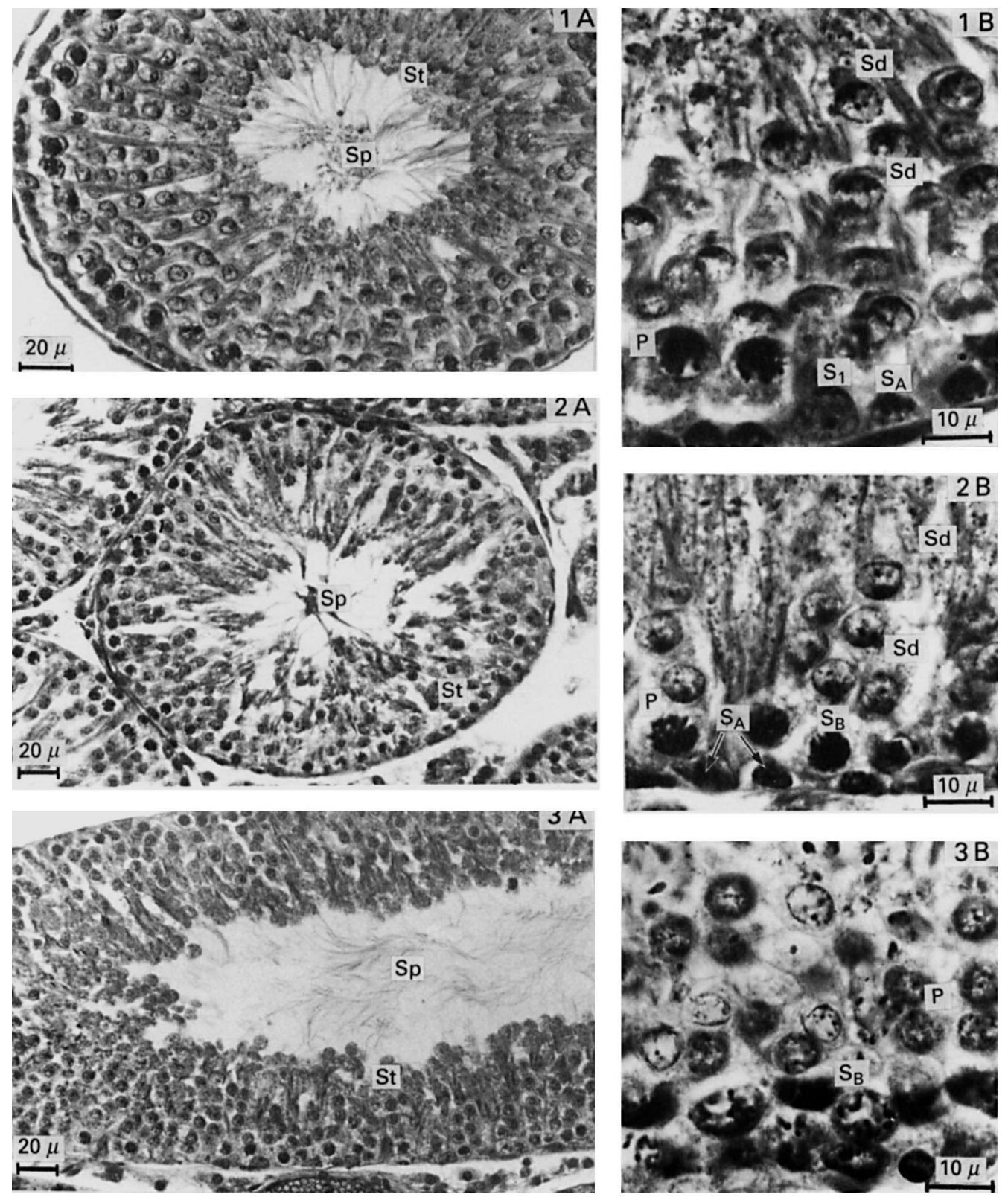

Plate 2. Testis seminiferous tubule of rats fed on balanced control diet (1 A, $1 \mathrm{~B})$, maize-cottonseed flour-milk $(2 \mathrm{~A}, 2 \mathrm{~B})$ and rice-coltonseed flour-milk $(3 \mathrm{~A}, 3 \mathrm{~B})$ diets (for details of composition, see Tables 1 and 2 and pp. 270-27l) after a period of protein depletion. St, seminiferous tubule; $S_{A}$, spermatogonia $A ; S_{B}$, spermatogonia $B ; S_{1}$, primary spermatocyte; $P$, pachytene stadis; $S d$, spermatid; Sp, spermatozoa. 
Wichmann, K., Vaheri, A. \& Luukkanen, T. (1982). Inhibiting herpes simplex virus type 2 injection in human epithelial cells by gossypol, a potent spermicidal and contraceptive agent. American Journal of Obstetrics and Gynecology 142, 593-594.

Withers, W. A. \& Carruth, F. E. (1915). Gossypol, the toxic substance in cottonseed meal. Journal of Agricultural Research 5, 261-273.

Xue, S. P. (1981). Studies on the infertility effect of gossypol, a new contraceptive for males. In Recent Advances in Fertility Regulation pp. 122-145 [C. Chang, D. Griffin and D. Woolman, editors]. Geneva: Atar.

Ye, W. S., Liang, J. C. \& Tsu, T. C. (1983). Toxicity of a male contraceptive, gossypol, in mammalian cell cultures. In Vitro (Rockville) 19, 53-57. 